\title{
Improving Female Researchers' Careers through Gender Equality Plan actions: Experiences from a Slovenian Research Institution
}

\author{
Tanja Petrović \\ ZRC SAZU, Institute of Culture and Memory Studies \\ Novi trg 2, Ljubljana, Slovenia \\ cross' $^{\text {ref }}$ http://dx.doi.org/10.5755/j01.ppaa.20.1.28310
}

\begin{abstract}
This article draws on experiences in implementing the Gender Equality Plan adopted at the Research Centre of the Slovenian Academy of Sciences and Arts in early 2019. It discusses the careers of female researchers, their prospects for career advancement, and how their excellence is construed, negotiated, and promoted in the Slovenian academic sphere. The article proposes a contextualised understanding of female academic careers and excellence. This understanding is sensitive to the structural variables that define researchers' academic prospects, as these prospects result from the intersection of various personal and structural factors. It argues that in order to plan appropriate strategies for improving career prospects for female researchers in a Gender Equality Plan, it is necessary not only to consider the national context, the legislation and demographic and other "objective data", but also to take seriously the institutional culture and the fact that individual researchers are affected by neoliberal academia in different ways that depend on their structural position within the institution.
\end{abstract}

Keywords: gender equality plan, academic career, work-life balance, mentoring, promotion of research excellence, Slovenia

Raktažodžiai: Lyčiu lygybès planai, akademine karjera, darbo ir laisvalaikio balansas, tyrimu sèkmès skatinimas, Slovenija

\section{Introduction}

\section{Research excellence as a gender-biased and neoliberal construct}

Widely seen as an academic ideal, excellence occupies an important place in national and European policies and strategies for research and innovation, and it is perceived as the most important condition for the advancement of academic careers ${ }^{1}$. This concept, however, is not neutral and therefore needs to be carefully observed in relation to the ideological, social, cultural, and economic conditions that shape both what excellence is and how different groups of researchers can achieve it. Two important and interrelated factors affect how research excellence is construed, practised, and accessed, and these factors significantly shape the careers of researchers. The first factor reveals excellence to be a gender-biased construct. This casts doubt on the assumption that men's and women's (and other marginalised or minority groups') academic achievements are assessed on the same basis (Brouns \& Addis 2004: 11). This goes against the assumed objectivity, neutrality, and disinterestedness of the process through which academic results are assessed. It also goes against the common belief that academia is based on a meritocratic system (Wolffram 2018: 89; Bagilhole \& Goode 2001). The second factor points out the fact that academic work and excellence are not judged exclusively within academia's domain; academia's values and criteria - which would be a

\footnotetext{
${ }^{1}$ This article is based on the research done in the framework of the Horizon 2020 project R\&I PEERS (Pilot experiences for improving gender equality in research organisations, 2018-2022), funded by the European Commission (grant number 788171).
} 
prerequisite for an ethical science, as Robert Merton argued in his classic text (1942) - are also part of other social and economic structures. Many researchers argue that "pure" academia, independent of economic interest and relations, never existed (Radder 2010: 9-10) and that "the academic career system is based on the traditional male model of labour market participation" (Brouns and Addis 2004: 19) that idealises "linearity without interruption or career breaks and total availability and devotion to academia" (Cukut Kirilić et al. 2018: 146; see also Bozzon et al. 2017; Careless 2012; Wolf-Wendel \& Ward 2006). Other researchers point to the fact that the system of evaluation of research excellence has been increasingly subjected to the neoliberal logic of "the commodification of academia through profit-oriented policies" (Hofman 2021: 84; see also Barry, Chandler, \& Clark 2001; Fakin Bajec \& Sitar 2017).

These two factors are highly relevant to academic careers in the Slovenian context as well. This article discusses the careers of female researchers, their prospects for career advancement, and how their excellence is construed, negotiated and promoted in the Slovenian academic sphere. It also presents strategies to improve female researchers' careers that were implemented at a Slovenian research institution (the Research Centre of the Slovenian Academy of Sciences and Arts, ZRC SAZU) in the framework of the Gender Equality Plan (GEP). The discussion is based methodologically on a combination of quantitative approaches (statistical data analysis, survey results) and qualitative analysis, encompassing ethnographic interviews and discursive analysis of documents and policy texts. Two years after the official adoption of the GEP at ZRC SAZU, its implementation and early effects can be assessed. Consequently, this article also offers reflections on the impact of selected strategies, assessed through monitoring procedures based on qualitative and quantitative indicators.

In the next section, I provide an overview of the national socio-political and historical contexts that affect the working conditions and professional prospects of researchers in Slovenia. I then focus on the institutional framework, organisational culture and regimes of financing as equally relevant factors affecting the careers of female researchers (Hofman 2017; Fakin Bajec \& Sitar 2017; Murgia and Poggio 2019). The last part of this article provides a detailed discussion of experiences in implementing the GEP adopted at ZRC SAZU in early 2019. There is a particular focus on actions and strategies - and their outcomes - in three important domains covered by ZRC SAZU's GEP that shape female researchers' careers and define their possibilities in academia: mentoring, work-life balance, and the construction of excellence. This article argues that in order to devise appropriate strategies to improve female researchers' careers, it is necessary to consider the mechanisms of neoliberal academia that still make inequalities gendered, but also seriously affect researchers across gender lines. This is why an intersectional approach to gender equality has been strongly advocated by researchers who warn against essentialising gender as an organising principle of inequality in academia, while ignoring other categories (Agustín 2013). In designing strategies for structural change, the term Gender+ has been used increasingly to recognise "that gender inequality and other inequalities are connected and are thus best addressed with those possible intersections in mind" (Verloo et al. 2011: 4,quoted after Tzanakou et al. 2020: 16). Moreover, the experience with the GEP implementation at ZRC SAZU has shown that the inequality-producing mechanisms of neoliberal academia affect persons differently depending on their position within the complex (and ever more diversifying) structure of the scientific sector. A person's position is determined by the stability of their contract, their career-progress options, work-related requirements, and the extent to which work interferes with their private life. Individuals would, in turn, recognise strategies to improve research careers as more or less necessary and effective (and consequently supported or not) in relation to their position within this complex structure.

\section{The national context: females' (researchers') careers in Slovenia}

The legislation and existing welfare provisions make Slovenia a society favourable to women's inclusion in the labour market. As stated in the report on the national context of gender equality in Slovenia, prepared as part of the R\&I PEERS project (Petrović, Mihajlović Trbovc, \& 
Hofman 2018: 20), "women in Slovenia have 'traditionally' high labour market participation rates: in 2016, 66\% of women were employed. However, it is still lower than the general participation rate of men, which was 74\% in 2016 (Report on Equality between Women and Men in the EU, 2017: $10) "$.

This report also indicates that the percentage of those in part-time employment is $9.7 \%$, which is significantly below the EU-27 average (17.6\%). As concerns the number of women working parttime, Slovenia displays a tendency to a slight percentage increase, from $13 \%$ in 2014 to $13.5 \%$ in 2017, albeit still far below the EU average (26.8\%). This discrepancy is particularly visible in the percentage of part-time employed women with two children aged under six years, which is $17.1 \%$ in Slovenia, compared with the EU average of $41.5 \%$ (EUROSTAT 2018). In the research and higher education sector, $4.1 \%$ of women and $7.2 \%$ of men work part-time, which is significantly below the EU average (13.5\% of women and 8.5\% of men) (SHE Figures 2015: 102). One of the important reasons for this is the fact that Slovenia provides a rather wide-ranging and all-encompassing system of childcare facilities. According to OECD data (2014), 40.3\% of all children under the age of two attend childcare facilities while the proportion of children aged three to five enrolled in pre-primary education is $87.2 \%$. Both figures are clearly above the EU averages of $34.4 \%$ and $85 \%$, respectively. (Petrović, Mihajlović Trbovc \& Hofman 2018: 20).

Despite their large-scale participation in the labour market, women in Slovenia are underrepresented in decision-making positions. While the share of women on boards $(15 \%)$ is higher than the EU average (14\%), the share of women in the national government stands at $8 \%$, which is far below the EU average (26\%). The gender pay gap is well below the EU-27 average. In Slovenia, women earned $4.4 \%$ less than men in 2010, while the EU-27 average was $16.4 \%$ (Černič Istenič et al. 2015: 186). However, this percentage has gradually increased to as much as $7.8 \%$ in 2016 , compared with an EU-27 average of 16.2\% (EUROSTAT 2016, op. cit. Petrović, Mihajlović Trbovc \& Hofman 2018: 20).

According to statistical data, in Slovenia in 2013, the number of women surpassed the number of men on bachelors, masters, and doctoral study programmes. Women amount to $64 \%$ of all students enrolled on masters study programmes (ibid.). The 2018 SHE figures (i.e. EU statistics on gender equality in the workplace) indicate that $61 \%$ of $\mathrm{PhD}$ graduates are women, a figure well above the European average of $47.9 \%$. However, women are still represented mostly in traditionally "female fields" - education, medicine and social work, the social sciences, humanities, and arts. The lowest number of women work in science and technology, and the 2018 SHE figures indicate (p. 81) that Slovenia has experienced a stark decline in the annual growth in the number of women researchers in the natural sciences $(-6.5 \%)$.

Despite the guaranteed formal equality, the issue of equal opportunities for men and women in developing an academic career in Slovenia remains highly relevant. The 2015 report on female research careers in Slovenia, published as part of the GARCIA project, highlights the following issues:

- The gender pay gap in science persists (and has increased in recent years) mainly due to differences in benefits related to managerial positions.

- Vertical (men occupy most senior research and managerial positions in science) and horizontal (the division of typically male/female fields of science) segregation in science and research persists.

- Female scientists report discrimination by gender more often than male scientists.

- More female than male scientists report encountering obstacles in international scientific mobility.

- Female scientists report completing more administrative tasks than their male counterparts.

- Female scientists less often report that they have gained national research projects.

- Female scientists report having worse working conditions (in terms of space, research equipment, etc.) than male scientists. 

scientists.

- Female scientists experience significantly higher levels of work-family conflict than male

- Female scientists report that they are performing more household and childcare tasks than male scientists.

- Male scientists receive a significantly higher number of awards for their scientific research than female scientists.

- The main types of discrimination identified in existing research generally pertain mainly to non-membership in particular informal/interest groups, lobbies, and nepotism, which holds true for both male and female scientists (Černič Istenič et al. 2015: 227-228).

Slovenia fits the pattern characteristic of most East and Central European countries (e.g. for Estonia, see Talves 2016). Although female graduates and early-career researchers outnumber their male counterparts, male researchers are more numerous among the assistant, associate and full professors (this pattern is usually visualised as a "scissor diagram"). The gender composition of heads of research-programme groups (programme groups enjoy relative stability in Slovenia's researchfinancing scheme) is also quite illustrative of inequalities in research and innovation in Slovenia. In April 2014, 242 heads of programme groups were men and 64 were women (20.9 \%) (Černič Istenič et al. 2015: 226). The statistics pertaining to the recipients of the most prestigious scientific awards in Slovenia (the Zois Awards) - similarly points to a gender disbalance: since 1998, only five women have received the life-achievement award (compared with $28 \mathrm{men}$ ), while eight women (compared with 59 men) have received the Zois award for extraordinary research achievements.

Above all else, the model of research funding applied in Slovenia makes the positions of earlycareer researchers particularly precarious and unstable. The prevalence of project-based financing makes it impossible to strategically plan one's career, as researchers often work on the projects that assure their salaries and not on those that would be most meaningful for their career development. They also work on multiple projects simultaneously and frequently switch their research priorities depending on the available financing.

\section{Perceptions of gender equality at ZRC SAZU}

The Research Centre of the Slovenian Academy of Sciences and Arts (ZRC SAZU) is a public research institution. It is one of the largest research institutions in the country, with almost 400 employees. Its research activities are performed by researchers organised in 18 independent (but closely interrelated) institutes.

The 2019 statistics indicate that female researchers outnumber their male colleagues in all positions and career phases except the highest one, for which there are more male research advisers than female research advisers. In the second-highest position (senior research associate), the number of female researchers is only slightly higher than the number of male researchers (see the graph below). 


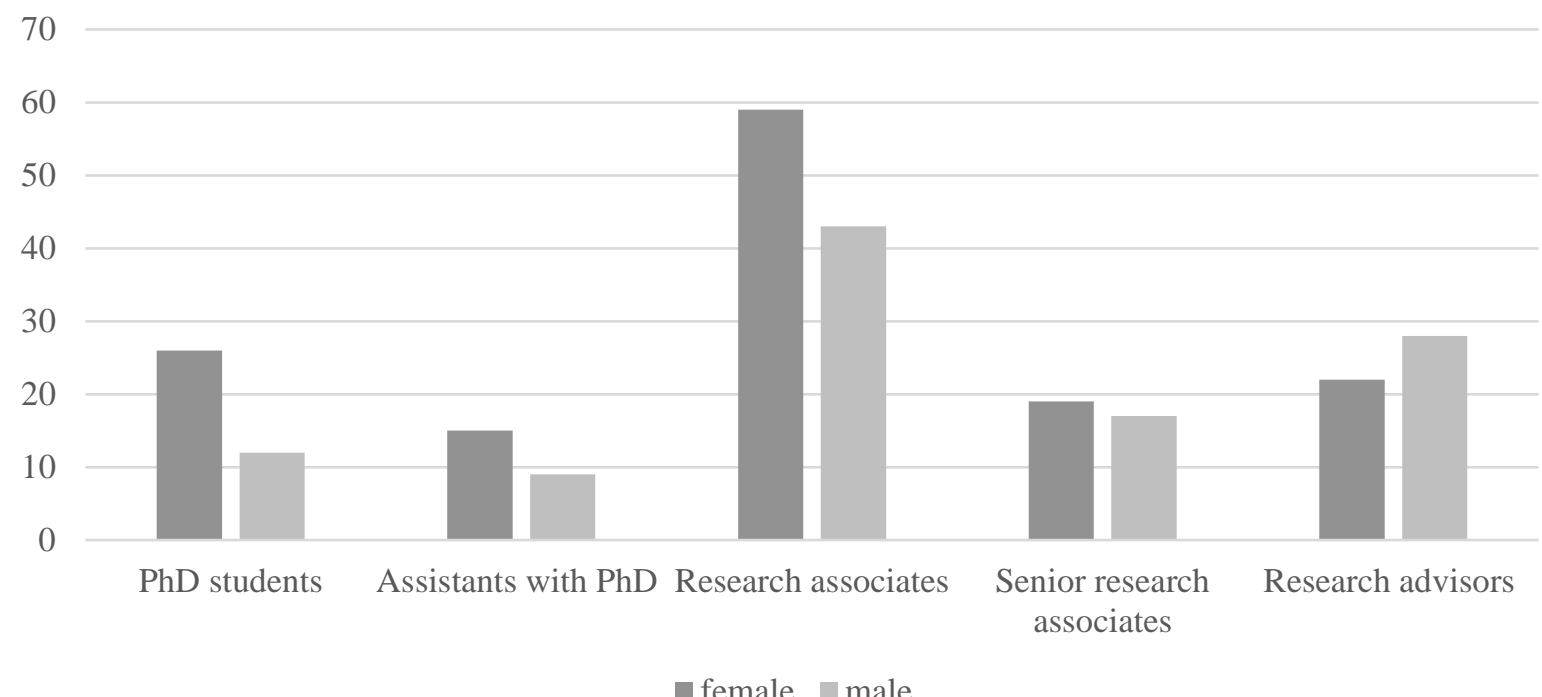

Fig.1. The gender of the research staff at ZRC SAZU Source: ZRC SAZU.

In February 2019, ZRC SAZU officially adopted the Gender Action Plan, developed in the framework of the Horizon 2020 project R\&I PEERS (Pilot Experiences for Improving Gender Equality in Research Organisations $)^{2}$. The adoption of the GEP was preceded by preparatory research and analyses that revealed several specific features of the institutional culture relevant for gender equality in this research organisation in general and female researchers' careers in particular. One detail that was highly beneficial for the GEP design was the fact that in the period from 2013 to 2017, we had conducted extensive research into ZRC SAZU's organisational culture as a consortium member of the FP7 project GARCIA (http://garciaproject.eu/). A series of in-depth interviews with researchers at different career stages, with members of the administration, and with those in leadership positions was conducted. In addition, ZRC SAZU is one of the partners in the project Horizon 2020 project ACT (https://act-on-gender.eu/project) that runs alongside the R\&I PEERS project. Coordinating the "community of practice" (McDonald \& Cater-Steel 2017) named Alt+G (which stands for "Alternative Infrastructure for Gender Equality in Academic Institutions", http://altg.act-on-gender.eu/) as part of the ACT project enabled us to detect the most important structural issues that researchers themselves have recognised as problematic and as hindering their academic careers. The issues around which the members of Alt $+\mathrm{G}$ CoP have mobilised so far point to the problem of a lack of financial resources, to excellence (and funding) criteria that privilege those who are already in positions of power, as well as to the difficulties that early-career researchers face in attempting to establish career stability.

The survey of perceptions of gender equality at ZRC SAZU conducted in 2018 as part of preparatory activities for the GEP design and implementation also reveals the relevance of the latter point raised by Alt+G CoP members - that gender differences need to be observed in how they intersect with other structural aspects that define a researcher's position, with career stage being the most important. Indeed, the survey results suggested that ZRC SAZU employees in general share positive opinions on the state of gender equality in their institution. The results of bivariate statistical analysis show that a large majority of the employees find that men and women are treated equally at their institute or in their department, that they are equally able to develop their potentials, and that

\footnotetext{
2 The R\&I PEERS project principal aim is the implementation and improvement of seven gender equality plans in research- and innovation-focused organisations in the Mediterranean area (Spain, Italy, Cyprus, Tunisia, Israel, Greece, and Slovenia). It also aims "to create and validate pilot experiences that disrupt gender-biased approaches and unconscious rules that limit participation by and careers for women in research and innovation" (For more information, see the project website: http://ripeers.eu).
} 
they have equal access to, and an influence within, decision-making bodies and opportunities for career advancement. However, analysis of the data has shown that such opinions are significantly more prevalent among senior male research staff than among female ones, especially those in junior positions. For instance, almost all (94.9\%) of senior male researchers agree (or completely agree) with the statement that "men and women are treated equally in ZRC SAZU", while junior female researchers share the same opinion but at a significantly lower rate (73.2\% agree or completely agree). The most significant difference in opinions lies between precisely these two groups: while $64.1 \%$ of senior male researchers agree completely with this statement, only $19.5 \%$ of junior female researchers share this level of agreement. The starkest difference in opinion between senior male and junior female researchers was noted on the issue of whether men and women have equal opportunities for career advancement in ZRC SAZU. An exceptionally large majority (92.3\%) of senior male researchers agree or agree entirely that equal opportunities exist, while only $29.3 \%$ of junior female researchers would concur ${ }^{3}$.

These differences in perceptions of gender equality point to one of the aspects most relevant to a gender analysis of researchers' working conditions in Slovenia: the regime of financing, which reserves a relatively limited amount of resources for stable institutional financing through research programmes, and forces the majority of researchers to compete for the resources necessary for their salaries. This makes the positions of early-career researchers particularly unstable, precarious, and often dependent on cultural elements detached from the ideals of excellence. Consequently, one's position in the hierarchical structure emerges as the most relevant feature for the perception of gender (in)equality.

\section{The Gender Equality Plan at ZRC SAZU and female researchers' careers}

The Gender Equality Plan (GEP) at ZRC SAZU has been designed to consider the structural differences that condition different perceptions of gender equality within the organisation, the most relevant characteristics of the organisational culture, and the complex institutional structure too. The latter required careful consideration of differences between the particular ZRC SAZU institutes. The GEP covers five broad areas: mentoring, work-life balance, promoting the excellence of female researchers, raising awareness of gender equality in the organisation, and improving gender neutrality and sensitivity in ZRC SAZU documents ${ }^{4}$. While the actions planned in all five areas contribute to improving the careers of female researchers, three of them directly address this issue in aiming to provide early-career researchers in particular with support, tools, and skills to facilitate their career progress. These three areas are mentoring, work-life balance, and promoting the excellence of female researchers. This section describes in detail the strategies and actions planed within these three areas, highlighting their rationale, and providing insights into their implementation, monitoring, and improvement during the first two years of the GEP implementation at ZRC SAZU.

\footnotetext{
${ }^{3}$ Similar findings were obtained in a project that researched the medicine and social sciences staff at the University of Oxford in 2014: "the highest levels of gender disparity in the perceptions of the university culture ... were on gender equity and self-efficacy in career advancement" (Ovseiko et al. 2019: 183), the latter meaning confidence in "ability to progress in career and overcome barriers to advancement" (ibid: 170)

${ }^{4}$ Two important areas usually addressed by gender equality plans - gender balance in leadership and decision making and integration of the gender dimension into research and curricula - do not have a central position in ZRC SAZU's GEP because there is no significant gender disbalance in high management and decision-making positions. In contrast, the issue of integrating gender dimensions into research and teaching has been extensively dealt with as part of the GARCIA project. ZRC SAZU's team designed the Toolkit for Integrating a Gender-sensitive Approach to Research and Teaching (Mihajlović Trbovc, \& Hofman 2015) and has been organising workshops on this topic at ZRC SAZU and other researchperforming organisations in Slovenia and abroad.
} 


\section{Mentoring}

Recent studies (e.g. Brajdić Vuković 2014) show that the career success of young researchers depends to a significant extent on their early academic socialization, in which mentoring plays a critical role. The results of the survey conducted at ZRC SAZU in 2018 confirmed insights from previous research (GARCIA project, Knežević Hočevar 2017) that showed that despite the existing structural mentoring schemes for early-career researchers $(\mathrm{PhD}$ supervision, the national Young Researchers scheme), young academics lack the skills and tools to help them "survive" in a highly competitive and increasingly dynamic academic labour market that is particularly unfriendly to young female researchers. Our ethnographic research, on the other hand, revealed that a rather conservative understanding of mentoring still prevails among senior researchers, limited to guiding a student towards successfully completing their doctoral dissertation.

As a response to the needs of early-career researchers, which were clearly expressed in the survey and the interviews, the mentoring-related strategies included in the GEP are directed primarily at providing them with skills that can increase their opportunities for career advancement. They are designed to help early-career researchers with career planning (workshops on international fellowships, workshops on successful project applications, ERC workshops, campaigns for strengthening career capacities) and acquiring knowledge and skills necessary for career advancement (workshops on communication skills, leadership skills, project writing, academic writing, and presentation skills). These strategies are expected to result in an increase in the number of national and international grants awarded to ZRC SAZU's early-career researchers. This would increase not only the excellence of research but also the institutional capacity to secure more stable positions for early-career researchers. An essential focus of ZRC SAZU's GEP in the field of mentoring is on information availability and the exchange of knowledge and best practices as prerequisites for making appropriate career choices and decisions. Strategies include seminars for the newly employed and annual workshops on promotion criteria and how to achieve them. Some strategies are directed at providing mentors with appropriate mentoring skills and exchanging best practices among mentors from Slovenian academic institutions. The GEP also includes strategies that aim to raise an awareness of the need for appropriate mentoring and GE in career paths; they include the annual collection and presentation of gender-segregated statistical indicators of the career paths of early-career researchers, and the publishing of statistics on researcher structure at ZRC SAZU with respect to gender and seniority of position in the annual report.

\section{Work-life balance}

In designing strategies that sought to reconcile a person's professional and private life, we departed from the fact that "Slovenian legislation enables a high degree of gender equality and the possibility to balance work and private life" (Petrović, Mihajlović Trbovc, \& Hofman 2018: 24). Thanks to the welfare state policies established during Yugoslav socialism, Slovenia has a widespread "network of childcare facilities and the provision of different types of paid leave of considerable duration for employed parents" (Cukut Kirilić et al., 2018: 150-151). Free afterschool care is also provided for children up to the age of 11 . To prevent discrimination in academic career advancement, "the Slovenian national research agency (ARRS) excludes time spent on maternity or parental leave from evaluation procedures" (Ibid.: 170).

As the research providing organisation, ZRC SAZU continually invests significant efforts in improving the opportunities available for striking a good balance between one's professional and private life. Since 2017, additional financial support for families has been made available for more extended stays abroad. This makes it easier for a researcher who has received a grant or fellowship to be accompanied by their family. Various free opportunities to improve health and wellbeing have been offered to employees: sports training sessions, lectures, medical check-ups, sports days, and special days dedicated to mental and physical health. Formally, all employees have the option of working remotely, but there is a huge diversity in the extent to which and how this option has been used. 
Despite the national legislative context and supportive institutional policies that facilitate reconciling work and life, work-life balance remains an important issue for ZRC SAZU researchers - particularly for women at early stages in their academic careers. This very demanding period in an academic career coincides with a time in their lives when they are intensely engaged in family planning, child-rearing, and caring for elderly parents. On the other hand, it is important to keep in mind a point that several researchers have emphasised recently: we cannot speak of a clearly gendered division between labour and family anymore, since women are active in all spheres of life outside the family domain, while an increasing number of men are taking on family duties and responsibilities (Laimiš 2015: 11; McElwain et al. 2005; Vladimirov 2005). Balancing demanding requirements in the spheres of their professional and private life, along with the precarisation and flexibilisation of work and the constant availability (made possible by modern technologies), all pose numerous challenges to both female and male researchers.

The career stage, as well as the researcher's position within the hierarchical structures, stood out as the most relevant factors in defining the necessity of improving work-life balance in such a way as to ensure female researchers' career advancement and excellence. The survey has shown that at ZRC SAZU employees are generally satisfied with the institution's policies that relate to work-life balance: a total of $68 \%$ of them agreed (or strongly agreed) with the statement, "In general, ZRC SAZU provides satisfactory services helping to balance professional work and private life". Nevertheless, among the concrete measures that would improve the reconciling of work and private life for researchers, as many as $77 \%$ of respondents considered financial support for families for longer stays abroad to be important ${ }^{5}$. A particularly high number of employees who responded to the survey considered the possibility of remote work (89\%) and flexible working hours (91\%) important for employees' work-life balance. A closer look at the survey results reveals the structural position within the organisation as being more decisive in shaping respondents' attitudes toward proposed measures than their gender: researchers (as opposed to administrative staff) and early-career researchers (as opposed to their senior colleagues) were those who recognised in significant numbers the need for these measures. Moreover, female researchers viewed flexible working hours and the possibility of remote work as a particularly important mechanism, while female administrative staff did not share this opinion: as one of them stressed, "bringing work home would only blur the boundary between work and private time, at the expense of the latter".

ZRC SAZU's GEP focuses mainly on the improvement of existing practices that relate to work-life balance. It includes data-collecting strategies that could ensure better insight into actual needs and provide feedback on the appropriateness of existing measures, along with suggestions for their improvement. In addition, the GEP pays particular attention to the availability of working from home and flexible working hours as one issue singled out in the survey, particularly by early-career researchers, as key in assuring a good balance between their professional and private life and in advancing their research careers. While working from home is officially permitted at ZRC SAZU, there are significant differences in the policies and practices permitted at particular institutes: at some, this option is widely available and used, while at others, it is instead an exception to the implicit workplace rule - and this sometimes relates to the collective or laboratory-bound nature of the research performed.

ZRC SAZU's GEP opts for a "soft" approach towards increasing the availability and use of opportunities to work from home. The aim of the actions planned is to increase the availability of the option to work from home (through a document signed by one of the institute heads for each researcher), thus making the positions of more of ZRC SAZU's employees equal in this respect. Topdown imposition of working from home as an universal option has not been considered because the autonomy of the research institutes is central to ZRC SAZU's institutional philosophy. The institutes and research groups within them also significantly diverge regarding the nature of research

\footnotetext{
${ }^{5}$ This measure has already been implemented at ZRC SAZU as one of the elements of the structural change introduced as part of the GARCIA projects.
} 
conducted, and this would therefore make it inappropriate to impose certain work regimes. Moreover, the ethnographic research conducted at ZRC SAZU in the framework of the GARCIA project and insights from recent literature suggests that work-life measures are ambiguous and have different effects on different groups of employees and individuals. For example, on the one hand, the interviews revealed that the blurred line between work and free time, which is generally perceived as a problem, has been viewed in a positive light by several younger researchers, as the possibility of working "anywhere" facilitates a flexibility and organisation of time that best suits both their professional and personal needs (Petrović 2017). On the other hand, working from home is not always the preferred option of the researchers themselves - some like to change the work environment frequently, and some have important social networks at the workplace that positively impact on their wellbeing and quality of life. The lockdowns caused by the Covid-19 pandemic in 2020 and 2021, which imposed working from home on researchers for a significant period, somewhat dramatically proved this point. Efforts had to be made in the opposite direction: to provide a safe working environment for those researchers whose conditions at home were not at all suited to long-term academic work. Because of the pandemic, all ZRC SAZU employees now have the formal possibility of working from home. In the next phases of the GEP implementation, after returning to regular modes of work, we will monitor the degree to which working from home will actually be used by employees as an option they can choose.

\section{Promoting the excellence of female researchers}

The statistics on awards-related practices at ZRC SAZU over a 20 year period (1998-2018) display particularly strong disparities concerning the gender of award recipients, thus replicating the situation present at the national level (see above). Currently, more female than male researchers are employed at ZRC SAZU, but the data show that male researchers received most awards, with men leading in all categories. Specifically, 18 men and nine women have received the Gold Award, and ten men and five women have received the Silver Award. In the period under study, not a single woman became an ZRC SAZU Member of Honour, an award given to top researchers who make an important contribution to establishing the importance of ZRC SAZU at home and abroad.

An analysis of practices to promote research results and excellence also indicates disparities related to gender and position in the hierarchy: on the ZRC SAZU official website, news items advertising research achievements by male and senior researchers decisively outnumber news items promoting research results achieved by female or early-career researchers.

This was also confirmed by the survey respondents - the results report a high number of perceptions of gender equality, but also a significant number of people who believe that men are prioritised over women in awards and in institutional recognition of their achievements. This prioritising also extends to the publicising and promotion of women researchers' work. While the majority of respondents in all groups agreed that there are no differences in awards or recognition in relation to gender, male researchers supported that idea much more so $(87.2 \%$ of seniors and $95.8 \%$ of juniors) than female researchers (60\% of seniors and $56.1 \%$ of juniors). Age and position within the hierarchy had a significant impact on perceptions of gender equality in relation to the promotion of research results and excellence: in total, $89.7 \%$ of senior male, $75 \%$ of junior male, $66.7 \%$ of senior female, and $63.4 \%$ of junior female researchers agreed with the statement that there are no genderbased differences in the provision of publicity to researchers and in the media promotion of their results.

In designing strategies to better promote the excellence of female researchers, we were aware of the complex relationship between the declarative and legal equality of all researchers, regardless of their gender, on the one hand, and power relations and inequalities stemming from patterns and practices in the institutional culture, which often give preference and visibility to men over women, on the other. The set of the strategies proposed in the ZRC SAZU's GEP within this area aims to systematically promote female researchers' excellence and strengthen researchers' competencies in promoting their results and achievements themselves. This encompasses coordinated PR campaigns, 
seminars, and workshops aimed at providing researchers with skills to promote their own research and achievements, as well as organising events that enhance cohesion and exchange between women who are at different stages in their academic careers. These strategies target PR officers, members of institutes that publish information on research activities, researchers, decision makers - and ZRC SAZU's academic community in general. The above-outlined results of the analysis of existing awarding and promotion practices have been made public and discussed at the board of directors. A series of events and campaigns promoting outstanding results by female researchers have been organised. These activities resulted in an increase in awareness of the importance of more diverse kinds of results and ways of promoting ZRC SAZU's employees. One consequence was the PR office taking a more proactive approach, while another was important changes to existing practices: for example, in 2020 - for the first time since 1995 - a woman was awarded the ZRC SAZU Member of Honour Award. It was bestowed upon Dr Heidemarie Uhl, a senior researcher at the Institute of Culture Studies and Theatre History at the Austrian Academy of Sciences and a lecturer at the universities of Vienna and Graz.

\section{Conclusions}

The analysis presented in this article demonstrates that in order to understand the obstacles to the advancement of women's academic careers in a specific context and to plan appropriate strategies for removing these obstacles, it is necessary not only to consider the national context, i.e. the legislation, the demographics and other "objective data", but to also take seriously the institutional culture and structural positioning of researchers, which is conditioned not only by their gender but also by other personal traits, and is governed by the logic of neoliberal academia (Ivancheva et al. 2019; Kinman 2014).

While the consequences of neoliberal regimes of academic work and prevalent organisational cultures remain gendered (Currie et al. 2000), it is both women and men who bear the consequences. Both their career prospects and perceptions of gender equality largely depend on their position within the hierarchical structure. This is defined by their gender, but also by their age, type of working contract, family situation, etc. Our efforts in the field of GE at ZRC SAZU have been met with support, solidarity, and interest by female, but also male employees, especially those able to personally recognise in their own experience the issues that we were raising.

The GEP that ZRC SAZU has implemented was designed to place a strong emphasis on horizontal connection, cohesion, and exchange between early-career researchers from different ZRC SAZU institutes. Through workshops, events, presentations of research results, and various initiatives, they have interacted, sharing and exchanging experiences and insights. This has proved to be a very useful dimension of the GEP, highly valued by early-career researchers as it facilitates a better intra-institutional cohesion, the efficient circulation of information and practical knowledge, yet also the exchange of information on various models of work organisation within the institutes that make up ZRC SAZU. Such a strongly positive response to the provision of a framework for horizontal connectivity and cohesion also indicated that one's structural position was very relevant in understanding researchers' careers and what is needed to improve career prospects.

The focus on structural positioning does not relativise the salient gendered inequalities but rather makes it possible to contextualise them properly, preventing the hypervisibility of female differences (Garforth \& Kerr 2009; see also Gregg 2011: 4-5) and challenging understandings of gender equality, inclusivity and diversity as being exclusively about women and for women.

\section{References}

1. Agustín, Lise Rolandsen. 2013. Gender Equality, Intersectionality and Diversity in Europe. New York: Palgrave Macmillan.

2. Bagilhole, Barbara M. \& Jackie Goode. 2001: "The Contradiction of the Myth of Individual Merit, and the Reality of a Patriarchal Support System in Academic Careers". The European Journal of Women's Studies 8(2): 161-180. 
3. Barry, Jim, John Chandler, and Hearher Clark. 2001. "Between the Ivory Tower and the Academic Assembly Line". Journal of Management Studies 38 (1): 87-101.

4. Bozzon, Rossella, Barbara Poggio, Annalisa Murgia, Elisa Rapetti. 2017. "Work-life balance in the early academic career stages. The case of precarious researchers in Italy". European Educational Research Journal, 16(2-3), 332351.

5. Brajdić Vuković, Marija. 2014. "The mentoring of young researchers in the natural and social sciences in Croatia". In (Re)Searching Scientific Careers, edited by Katarina Prpić, Inge van der Weijdenm Nadia Asheulova, $225-250$. St. Petersburg: Institute for the History of Sciences and Technology, St. Petersburg Branch, Russian Academy of Sciences, 225-250.

6. Brouns, Margo and Elisabetta Addis. 2004. "Part I - Synthesis Report on the Workshop ["Minimising Gender Bias in the Definition and Measurement of Scientific Excellence"]". In Gender and Excellence in the Making, Luxembourg: Office for Official Publications of the European Communities, 11-32.

7. Careless, Erin Jennifer. 2012. "Dueling clocks: mothers on the path to tenure". The Canadian Journal for the Study of Adult Education, 25(1), 31-46.

8. Cukut Krilić, Sanja, Majda Černič Istenič, and Duška Knežević Hočevar. 2018. "Work-Life Balance among Early Career Researchers in Six European Countries". In Gender and Precarious Research Careers: A Comparative Analysis, edited by Annalisa Murgia and Barbara Poggio, Abingdon and New York: Routledge, 145-177.

9. Currie, Jan, Patricia Harris, Bev Thiele. 2000. "Sacrifices in greedy universities: are they gendered?" Gender and Education, 12(3): 269-291.

10. Černič Istenič, Majda, Duška Knežević Hočevar, Sanja Cukut Kirilić, Tanja Petrović, Ana Hofman. 2015. Slovenia. In Contextualizing Women's Academic Careers: Comparative Perspectives on Gender, Care and Employment Regimes in Seven European Countries. GARCIA working paper 1, Trento: University of Trento, 185-242.

11. Fakin Bajec, Jasna and Polona Sitar. 2017. Neoliberalna politika in konstruiranje znanstvene odličnosti v slovenskem prostoru. In Znanost (brez) mladih: zgodnje stopnje znanstvene kariere v Sloveniji skozi perspektivo spola, edited By Ana Hofman, Ljubljana: Založba ZRC, 33-49.

12. Garforth, Lisa and Anne Kerr. 2009. "Women and science: what's the problem?" Social Politics: International Studies in Gender, State and Society, 16(3), 379-403.

13. Gregg Melissa. 2011. Work's Intimacy. Cambridge, Malden: Polity Press.

14. Hofman, Ana ed. 2017. Znanost (brez) mladih: zgodnje stopnje znanstvene kariere v Sloveniji skozi perspektivo spola. Ljubljana: Založba ZRC.

15. Hofman, Ana. 2021. Silenced Registers of Ethnomusicological Academic Labor Under Neoliberalism. In Transforming Ethnomusicology: Political, Social and Ecological Issues. Volume II, Beverley Diamond, Salwa ElShawan Castelo-Branco eds. New York: Oxford University Press, 83-95.

16. Ivancheva, Maria et al. 2019: "Precarity, gender and care in the neoliberal academy". Gender, Work \& Organization 26 (4): 448-462.

17. Kinman, Gail. 2014. "Doing More with Less? Work and Wellbeing in Academics". Somatechnics, 4 (2): $219-235$.

18. Knežević Hočevar, Duška. 2017. "Kako preživeti po doktoratu? Razmislek o mentorstvu. In Znanost (brez) mladih: zgodnje stopnje znanstvene kariere v Sloveniji skozi perspektivo spola, edited By Ana Hofman, Ljubljana: Založba ZRC, 127-157.

19. Laimiš, Aina. 2015. Ravnovesje med delom in zasebnim življenjem, delovna zavzetost in avtonomija delovnega časa. MA Thesis. Ljubljana: Univerza $\mathrm{v}$ Ljubljani, Filozofska fakulteta. Available from: https://psihologijadela.files.wordpress.com/2016/01/aina_laimis_magistrska.pdf

20. McDonald, Jacquie, and Aileen Cater-Steel, eds. 2017. Communities of Practice: Facilitating Social Learning in Higher Education. Singapore: Springer, 2017.

21. McElwain, Allyson K., Karen Korabik, and Hazel M. Rosin. 2005. “An examination of gender differences in workfamily conflict”. Canadian Journal of Behavioural Science 37(4): 283-298.

22. Merton, Robert K. 1942. The Sociology of Science: Theoretical and Empirical Investigations. Chicago and London: The University of Chicago Press.

23. Mihajlović Trbovc, Jovana and Ana Hofman. 2015. Toolkit for Integrating Gender Sensitive Approach into Research and Teaching. GARCIA working papers 6. Trento: University of Trento, available from: http://garciaproject.eu/wp-content/uploads/2015/12/GARCIA_working_paper_6.pdf

24. Murgia, Analisa and Barbara Poggio. 2019. Gender and Precarious Research Careers: A Comparative Analysis. London: Routledge. 
25. Ovseiko, Pavel, V., Linda H. Pololi, Laurel D. Edmunds, Jan T. Civian, Mary Daly, Alastair M. Buchan. 2019. "Creating a More Supportive and Inclusive University Culture: A Mixed-Methods Interdisciplinary Comparative Analysis of Medical and Social Sciences at the University of Oxford”. Interdisciplinary Science Reviews 44 (2): 166-191.

26. Petrović, Tanja. 2017. “'Čez vikende nikamor ne grem brez računalnika’: Usklajevanje poklicnega in zasebnega življenja in delo v akademski sferi”. In Znanost (brez) mladih: zgodnje stopnje znanstvene kariere v Sloveniji skozi perspektivo spola, edited By Ana Hofman, Ljubljana: Založba ZRC, 73-97.

27. Petrović, Tanja, Jovana Mihajlović Trbovc, Ana Hofman. 2018. Analysis of Country Guidelines (D.3.1). Pilot Experiences for Improving Gender Equality in Research Organizations (R\&I PEERS), 44pp.

28. Radder, Hans. 2010. The Commodification of Academic Research: Science and the Modern University. Pittsburgh: Pittsburgh University Press.

29. Report on equality between women and men in the EU. Brussels: European Commission, 2017, available from: https://ec.europa.eu/info/sites/info/files/aid_development_cooperation_fundamental_rights/annual_report_ge_201 7 en.pdf

30. SHE Figures 2015. Brussels: European Commission, 2016, available from: https://ec.europa.eu/research/swafs/pdf/pub_gender_equality/she_figures_2015-final.pdf

31. SHE Figures 2018. Brussels: European Commission, 2019, available from: https://op.europa.eu/en/publicationdetail/-/publication/9540ffa1-4478-11e9-a8ed-01aa75ed71a1

32. Talves, Kairi. 2016. "Discursive self-positioning strategies of Estonian female scientists in terms of academic career and excellence". Women's Studies International Forum 54: 157-166.

33. Tzanakou Charikleia, Shireen Chilcott, Kate Clayton-Hathway, Anne Laure Humbert. 2020: Key Prerequisites for a Europe-wide Gender Equality Scheme. CASPER Project, Horizon 2020, available from: https://zenodo.org/record/4428168

34. Verloo, Mieke, Feride Acar, Susanne Baer, María Bustelo Ruesta, Vlasta Jalušić, Lut Mergaert, Maria PantelidouMaloutas, Malin Rönnblom, Birgit Sauer, Tilly Vriend, Sylvia Walby, and Viola Zentai. 2011. Final QUING Report, Vienna: Institute for Human $\quad$ Sciences. Available from https://www.iwm.at/projects/quing/www.quing.eu/files/QUING_Final_Report_Jan\%2012.pdf

35. Vladimirov, Petra. 2005. "Do družine prijazni in hkrati konkurenčni”. Manager 3: 45-46.

36. Wolffram, Andrea. 2018. "Excellence as a Gender-Biased Concept and Effects of the Linking of Excellence with Gender Equality”. International Journal of Gender, Science and Technology 10(1): 88-107.

37. Wolf-Wendel, Lisa Ellen and Kelly Ward. 2006. "Academic life and motherhood: variations by institutional type". Higher Education 52, 487-521. 


\section{Tanja Petrović}

\section{Moterų karjeros gerinimas vykdant lyčių lygybės plano veiksmus: Slovẻnijos tyrimų institucijos patirtis}

Anotacija

Lyčių lygybės igyvendinimo planas, priimtas Slovėnijos mokslų ir meno akademijos tyrimų centre 2019 m. pradžioje. Šio plano ịgyvendinimas yra pagrindinis straipsnio tyrimų objektas. Jame aptariama mokslininkių karjera, jų karjeros perspektyvos bei kaip suvokiama jų kompetencija. Straipsnyje analizuojama kaip vyksta derybos dèl akademinès karjeros galimybių. Kontekstualus moterų akademinès karjeros vertinimas ir supratimas yra jautrus struktūriniams kintamiesiems, apibrěžiantiems mokslininkų akademines perspektyvas, nes šios perspektyvos atsiranda dèl įvairių asmeninių ir struktūrinių veiksnių sankirtos. Autore teigia, kad norint optimaliai moterų mokslininkių karjeros galimybes ir parinkti tinkamas igyvendinimo strategijas, lyčių lygybès plane reikia ne tik atsižvelgti ị nacionalinị kontekstą, teisès aktus ir demografinius bei kitus „objektyvius duomenis“, bet sistemingai ịvertinti ị institucinę kultūrą ir tai, kad neoliberali akademijos struktūra yra skirtingai patiriama ir vertinama pačių mokslininkių.

Tanja Petrović - researcher, ZRC SAZU, Institute of Culture and Memory Studies. E-mail: tanja.petrovic@zrc-sazu.si

Tanja Petrović - tyrèja, ZRC SAZU, Kultūros ir atminties studijų institutas. El. paštas: tanja.petrovic@zrc-sazu.si 